\title{
An Empirical Research: The Determining Factors of Capital Structure of Strategic Emerging Industry, Based on Data of Listed Enterprises in China
}

\author{
Jiachun Chen \\ Management School, Jinan University, Guangzhou, China \\ Email: 294818673@qq.com
}

Received 3 March 2015; accepted 12 April 2015; published 17 April 2015

Copyright (C) 2015 by author and Scientific Research Publishing Inc.

This work is licensed under the Creative Commons Attribution International License (CC BY).

http://creativecommons.org/licenses/by/4.0/

\section{c) (i) Open Access}

\begin{abstract}
This paper used relevant research of capital structure as reference in consideration of strategic emerging industry, pointed put forward nine hypotheses. The samples of the empirical research are 224 listed enterprises from Shanghai and Shenzhen stock markets in the year 2012. The research showed that trade factor had influence on capital structure, and profitability was the key influence factor. Besides, firm size, growth and asset liquidity were also the influence factors.
\end{abstract}

\section{Keywords}

\section{Strategic Emerging Industry, Listed Enterprises, Capital Structure}

\section{Introduction}

Strategic emerging industry plays an important part in national economy of China, which is knowledge-intensive with big growth potential. The concept of strategic emerging industry was put forward recently. The State Council of China issued a series of policies to promote the industry. At present, the relevant research of strategic emerging industry stopped proceeding at the level of theoretical study. This paper tried to study the capital structure of strategic emerging industry.

\section{Literature Review}

Along with capital structure theory, the research of determinations of capital structure is deepening. The deter-

How to cite this paper: Chen, J.C. (2015) An Empirical Research: The Determining Factors of Capital Structure of Strategic Emerging Industry, Based on Data of Listed Enterprises in China. Modern Economy, 6, 458-464. 
minations of capital structure include the external environment factors and firm's internal factors.

The external environment factors in corporate country related issues, macro-economic factors and industry factors. Collin and Sekely (1983) found that when the corporate headquarters were in different countries, its subsidiaries had different capital structures, and industry factors and macro-economic factors had nothing to do with capital structure [1]. Schwartz and Aronson (1967) found that enterprises in different industries had different capital structure, but the enterprises in the same industry had similar capital structure [2]. Salehi (2012) showed that country-specific factors can also influence corporate leverage indirectly through their impact on the effect of firm-specific factors [3]. Strategic emerging industry consists of 7 subordinate industries. There are similar qualities in these 7 industries. So to explore the similarities among them make sense.

The firm's internal factors consist of asset tangibility, non-debt tax shields, profitability, growth, asset size, liquidity and so on. Based on an conclusion of capital structure, containing agent cost, asymmetric information, interaction of strategic decision and control right, Harris and Raviv (1991) found that fixed assets ratio, non-debt tax shields, growth, asset size had positive correlation with leverage ratio, and bankruptcy risk, profitability, product uniqueness had negative correlation with leverage ratio [4]. Mallikarjunappa (2007) found that debt service capacity, non-debt tax shield, liquidity and business risk are the important determinants of the capital structure of pharamaceutical companies in India [5]. Baltaci (2014) found that leverage is significantly and negatively associated with tangibility, profitability, inflation and financial risk [6].

As to listed enterprises in China, there are some particularities. The ownership concentration degree is high and most of them are state-holding enterprise. Chang Chun (2014) identified profitability, industry leverage, asset growth, tangibility, firm size, state control, and the largest shareholding as reliable core factors explaining book leverage [7]. Dong Yan (2014) found that long-term debt ratio is positively related to firm size and asset tangibility while negatively related to profitability and growth opportunities [8]. Seelanath (2010) provide empirical evidence for the relationship between a firm's choice of capital structure and its productive environment using three basic hypotheses: efficiency risk, franchise value and political power [9]. So to study the capital structure of listed enterprises in China, we had to consider these two factors. The paper tried to study the capital of enterprises strategic emerging industry, in consideration of the actual conditions of China.

On the basis of findings already, the paper tried to collect data to explore the decision factors of capital structure of listed enterprises among strategic emerging industry. There are two definitions of capital structure: generalize capital structure and narrow capital structure. As to generalize capital structure, capital structure means the fund resource and structure of capital. Narrow capital structure means the resource and structure of long-term funds. In Empirical research, we used asset-liability ratio to represent capital structure.

\section{Research Design}

\subsection{Hypotheses}

Myers (1984) considered that asset-liability ratio were different in different industries, because the asset risks, types of asset and the external funding needs were different as the industries changed. Kester (1986) found that industry factor is the influence factor of capital structure, when he compared the capital structure of enterprises in China. Strategic emerging industry consists of 7 subordinate industries: new energy, new motor vehicle, highend equipment manufacturing, new information technology, energy conservation, new materials and biopharmaceutical industry. We believed that there were differences among these seven industries, so we put forward hypothesis 1: industry factor is the influence factor of capital structure.

When the size of the company is large, it tends to adopt diversified operation. Major corporations have stable cash flow and its anti-risk power is strong, which make the bankruptcy cost lower [10]. Because the bankruptcy cost is low, major corporations are willing to adopt high liabilities. As the information asymmetry, financial situation of smaller company is not transparent, while major corporate can provide more information, which make creditors know much about it. Creditors are more willing to lend to major corporates than small companies. Besides, in China, major corporates make great contribution to local economy, which receives much attention of local government. Local government can offer support in bank loans. So hypothesis 2 is: The size of firm has positive correlation with asset-liability ratio.

Strategic emerging industry is a new industry, which has great potentials and fast development. And in harmony with this, significant funding is needed. Because in developmental levels, shareholders have absolute control over the corporate, and issuing new shares implies dilution of control of existing shareholders. With a beau- 
tiful prospect of the corporate, existing share holders hope to make more revenue over the long term, so they do not hope the corporate will accept more new shareholders. The corporate prefer to debt rather than equity financing. Hypothesis 3 is: Growth has negative correlation with asset-liability ratio.

The value of tangible assets is more than intangible assets in bankrupt. Tangible assets are influenced weakly by the information asymmetry. Tangible assets transmit signals that the assets are safe when guaranteed. Even the debtor defaults, creditors can sell the guaranteed assets to cover losses. In China, the commercial banks ask corporate to offer pledge of movables, and intangible assets are hard to be evaluated. So the commercial banks prefer to serve a loan to corporate with guaranteed tangible assets. So the corporate with more tangible assets can get loan more easily. Based on analysis above, hypothesis 4 is: The Tangible assets ratio has positive correlation with asset-liability ratio.

The products of strategic emerging industry are unique with a lack of replacements. Customers are hard to find replacements when buy the products of these corporate. If the ruin probability of the corporates is high, the demand will decline sharply. To reduce the ruin probability, corporate will reduce debt. So hypothesis 5 is: the unique of the products has negative correlation with asset-liability ratio.

In China, one share being overwhelming big exists in listed corporates. Big shareholders have dominant control of the firm. Besides, with the imperfect professional manager market, the management is dispatched by the big shareholders. The management tends to maintained big shareholders' rights, and the big shareholders may occupy small shareholders' interests. Equity financing has debt repayment. Big shareholders will prefer to adopt equity financing to occupy small shareholders' interests. So hypothesis 6 is: shareholding concentration has negative correlation with asset-liability ratio.

The non-debt tax shield such as depreciation and investment tax credit is the replacement of debt. Corporate with much non-debt tax shield prefer to adopt less debt [11]. So, when there is much non-debt tax shield, the motivation of debt will be weak. Besides, the non-debt tax shield can avoid debt repayment risk. Hypothesis 7 is: The non-debt tax shield has negative correlation with asset-liability ratio.

The corporate with more liquid assets prefer to invest by these liquid assets. Asset liquidity means that the corporate can manipulate the asset basing on the interest of creditor [12]. Taking this into account, the creditor will not lend to the corporate. So hypothesis 8 is: asset liquidity has negative correlation with asset-liability ratio.

Generally speaking, the stronger the profitability is, the more internal financing will be adopted. Because the cost internal financing is less than debt financing and equity financing. The corporate are more willing to adopt internal financing. So hypothesis 9 is: profitability has negative correlation with asset-liability ratio.

\subsection{Variables Setting}

The paper set 1 explained variable and 8 explanatory variables. Every variable was represented by index, which can be gotten from annual reports of listed corporates. The variables were shown in Table 1.

The control variable is industry factor. Based on biopharmaceutical industry, other 6 industries can be transported into dummy variable.

$$
\mathrm{Di}=\left\{\begin{array}{c}
1 \text { represent industry } \mathrm{i} \\
0 \text { represent other industries }
\end{array} \mathrm{i}=1,2,3,4,5,6\right.
$$

(1-new energy; 2-high-end equipment manufacturing; 3-new motor vehicle; 4-new information technology; 5-energy conservation; 6-new materials)

\subsection{Samples and Research Method}

The paper adopted 264 listed enterprises among strategic emerging industry, which were published by Wind Database. The samples were shown in Table 2. The number of samples in each industry is different, but it will affect the empirical results, because we had adopted the industry factor as the control variable.

When studying the industry factor, the paper adopted chi-square test. To explore the explanatory variables, autocorrelation test was adapted. It showed that variables autocorrelation existed among some explanatory, so it is not suitable to adopt linear regression theory directly. The paper used progressive regression method. Progressive regression method can exclude non-significant explanatory variables. 
Table 1. Variables setting.

\begin{tabular}{lccc}
\hline \multicolumn{1}{c}{ Types } & Variables & Abbreviation & Index \\
\hline Explained variable & Capital structure & LEV & Asset-liability ratio \\
Size & SIZE & Natural logarithm of total assets \\
& Growth & GROWH & (Final total assets-initial total assets)/Initial total assets \\
& Thique of the products & UP & (Inventory + fixed assets)/Total assets \\
Explanatory variables & Shareholding concentration & SC & Sales expenses/Sales revenue \\
& Non-debt tax shield & NTS & Stock proportion of the first shareholder \\
& Asset liquidity & AS & Depreciation/Total assets \\
& Profitability & PRO & Current assets/Current liabilities
\end{tabular}

Table 2. Samples.

\begin{tabular}{cc} 
Industries & Amounts \\
\hline High-end equipment manufacturing & 31 \\
Energy conservation & 12 \\
Biopharmaceutical industry & 34 \\
New material & 97 \\
New energy & 108 \\
New motor vehicle & 17 \\
New information technology & 180 \\
\hline
\end{tabular}

\section{Empirical Results}

\subsection{Descriptive Statistics}

Based on analysis above, the asset-liability ratios of 224 listed enterprises among strategic emerging industry were shown in Table 3. The sample comes from wind database.

From Table 1 we can conclude that the average asset-liability ratio of high-end equipment manufacturing and new motor vehicle were similar, all of which were more $50 \%$. The average asset-liability ratio is the lowest, just $28.2 \%$.

\subsection{Analysis of Control Variable}

The paper supposed industry factor as an influence factor. Now we will make an analysis of it. We adopt KruskalWalls $\mathrm{H}$ test. Kruskal-Walls $\mathrm{H}$ test are used to test independence of different samples. The test drew the sample from $\mathrm{k}$ unordered sample to test omnidirectional problems. The result of the test was shown in Table 4 and Table 5 .

From Table 5, the value of chi-square was 33.217, and degree of freedom was 2 . When it was supposed that the average asset-liability ratio of 7 industries had no difference, the possibility of bilateral inspection probability is 0 . So the conclusion is that the average asset-liability ratio was significant different across 7 industries. Hypothesis 1 was confirmed.

\subsection{Correlation Analysis}

Because sample distribution was unknown, so spearman rank correlation coefficient was adopted. The result of correlation analysis was shown in Table 6. 
Table 3. Average asset-liability ratios of different industries.

\begin{tabular}{cc}
\hline Industries & Average asset-liability ratio \\
\hline High-end equipment manufacturing & 0.5251 \\
Energy conservation & 0.3673 \\
Biopharmaceutical industry & 0.2820 \\
New material & 0.4637 \\
New energy & 0.5589 \\
New motor vehicle & 0.5082 \\
New information technology & 0.4226 \\
\hline
\end{tabular}

Table 4. Mean rank.

\begin{tabular}{ccc}
\hline Industry & N & Mean rank \\
\hline Biopharmaceutical industry & 32 & 66.91 \\
New energy & 32 & 146.81 \\
High-end equipment manufacturing & 32 & 122.75 \\
New motor vehicle & 32 & 133.72 \\
New information technology & 32 & 105.97 \\
Energy conservation & 32 & 91.31 \\
New material & 32 & 120.03 \\
\hline
\end{tabular}

\section{Table 5. Test statistics.}

\begin{tabular}{cc}
\hline & LEV \\
\hline Chi-square & 33.217 \\
df & 6 \\
Progressive significance & 0 \\
\hline
\end{tabular}

Table 6. Correlation coefficient.

\begin{tabular}{|c|c|c|c|c|c|c|c|c|}
\hline & Size & Growth & TA & UP & SC & NTS & AS & PRO \\
\hline SIZE & 1 & & & & & & & \\
\hline GROWTH & -0.059 & 1 & & & & & & \\
\hline TA & $0.223^{* *}$ & $-0.144^{*}$ & 1 & & & & & \\
\hline UP & $-0.275^{* *}$ & 0.091 & $-0.358^{* *}$ & 1 & & & & \\
\hline SC & 0.115 & 0.004 & 0.101 & $-0.261^{* *}$ & 1 & & & \\
\hline NTS & $0.157^{*}$ & $-0.270^{* *}$ & $0.672^{* *}$ & $-0.321^{* *}$ & $0.134^{*}$ & 1 & & \\
\hline AS & $-0.524^{* *}$ & $0.152^{*}$ & $-0.466^{* *}$ & $0.356^{* *}$ & -0.116 & $-0.435^{* *}$ & 1 & \\
\hline PRO & $-0.256^{* *}$ & $0.346^{* *}$ & $-0.356^{* *}$ & $0.296^{* *}$ & -0.118 & $-0.326^{* *}$ & $0.619^{* *}$ & 1 \\
\hline
\end{tabular}

"Correlation is significant at the 0.05 level (2-tailed); ${ }^{* *}$ Correlation is significant at the 0.01 level (2-tailed). 
From Table 6, many explanatory variables were correlated with each other, which means strong correlation exist. It is not appropriate to adopt multiple linear regressions directly, because multicollinearity will make the model unstable. So the paper will adopt stepwise regression.

\subsection{Results of Stepwise Regression}

With stepwise regression, five models were gotten, which was shown in Table 7. The R square of model 5 was 0.728 , which is the largest in the five models. It means the degree of fitting of model 5 is the best. Besides 0.728 is between 0.6 and 0.8 , which can be accepted. The predators of model 5 consisted: D6, D5, D3, D2, D4, D1, PRO, SIZE, AS and GROWTH. So these four explanatory variables were the influenced factors.

Table 8 showed the anova of model 5 . The value of $\mathrm{F}$ is 56.896, and its significance is 0 , which showed the regression was significant.

From the results above, the explanatory variables of the model is PRO, SIZE, AS and GROWTH. TA, UP, SC and NTS were excluded. So tangible assets ratio, unique of the products, non-debt tax shield and shareholding concentration had nothing to do with capital structure. Hypothesis 3, 4, 5 and 6 were not supported.

Table 9 showed the coefficients of model 5. The coefficients of AS, GROWTH, AS and PRO were 0.079, $0.043,-0.014$ and -0.926 . All of them are significant at the 0.05 level. So the size of the firm has positive cor-

Table 7. Model summary.

\begin{tabular}{ccccc} 
Model & $\mathrm{R}$ & R Square & Adjusted R square & Std. Error of the Estimate \\
\hline 1 & $0.360^{\mathrm{a}}$ & 0.130 & 0.106 & 0.2371623 \\
2 & $0.742^{\mathrm{b}}$ & 0.551 & 0.536 & 0.1708217 \\
3 & $0.829^{\mathrm{c}}$ & 0.687 & 0.675 & 0.1429291 \\
4 & $0.850^{\mathrm{d}}$ & 0.722 & 0.710 & 0.1349427 \\
5 & $0.853^{\mathrm{e}}$ & 0.728 & 0.715 & 0.1339163 \\
\hline
\end{tabular}

a Predators: (constant), D6, D5, D3, D2, D4, D1; 'Predators: (constant), D6, D5, D3, D2, D4, D1, PRO; 'Predators: (constant), D6, D5, D3, D2, D4, D1, PRO, SIZE; ' ${ }^{\mathrm{d}}$ Predators: (constant), D6, D5, D3, D2, D4, D1, PRO, SIZE, AS; ' Predators: (constant), D6, D5, D3, D2, D4, D1, PRO, SIZE, AS, GROWTH.

Table 8. Anova.

\begin{tabular}{ccccccc}
\hline & Model & Sum of Squares & df & Mean Square & F & Sig. \\
\hline \multirow{2}{*}{5} & Regression & 10.204 & 10 & 1.020 & 0.000 & \\
& Residual & 3.820 & 213 & 0.018 & \\
& Total & 14.023 & 223 & & \\
\hline
\end{tabular}

Predictors: (constant), D6, D5, D3, D2, D4, PRO, SIZE, AS, GROWTH; Dependent Variable: asset-liability ratio.

Table 9. Coefficients.

\begin{tabular}{|c|c|c|c|c|c|c|}
\hline & \multirow{2}{*}{ Model } & \multicolumn{2}{|c|}{ Unstandardized Coefficients } & \multirow{2}{*}{$\begin{array}{c}\text { Standardized Coefficients } \\
\text { Beta }\end{array}$} & \multirow{2}{*}{$\mathrm{t}$} & \multirow{2}{*}{ Sig. } \\
\hline & & B & Std. Error & & & \\
\hline \multirow{11}{*}{5} & (Constant) & -1.129 & 0.197 & & -5.740 & 0.000 \\
\hline & D1 & -0.025 & 0.037 & -0.036 & -0.689 & 0.492 \\
\hline & D2 & -0.086 & 0.038 & -0.120 & -2.273 & 0.024 \\
\hline & D3 & -0.065 & 0.037 & -0.092 & -1.760 & 0.080 \\
\hline & D4 & -0.023 & 0.035 & -0.032 & -0.648 & 0.517 \\
\hline & D5 & -0.054 & 0.034 & -0.076 & -1.578 & 0.116 \\
\hline & D6 & -0.046 & 0.036 & -0.065 & -1.299 & 0.196 \\
\hline & PRO & -0.922 & 0.058 & -0.645 & -15.989 & 0.000 \\
\hline & SIZE & 0.079 & 0.009 & 0.370 & 8.719 & 0.000 \\
\hline & AS & -0.014 & 0.002 & -0.274 & -5.592 & 0.000 \\
\hline & GROWTH & 0.043 & 0.021 & 0.093 & 2.072 & 0.039 \\
\hline
\end{tabular}

Dependent Variable: LEV. 
relation with asset-liability ratio. Asset liquidity and profitability had negative correlation with asset-liability ratio. Hypothesis 1, 7 and 9 were confirmed. The significance between GROWTH and LEV is under 0.05 . So the growth has positive correlation with asset-liability ratio. Hypothesis 2 was confirmed.

The final regression model is:

$$
\begin{aligned}
L E V= & -1.129+0.079 \mathrm{SIZE}-0.043 \mathrm{GROWTH}-0.014 A S-0.922 P R O-0.025 D_{1}-0.086 D_{2} \\
& -0.065 D_{3}-0.023 D_{4}-0.054 D_{5}-0.046 D_{6}
\end{aligned}
$$

\section{Conclusion}

The conclusions were: trade factor had influence on capital structure, and profitability was the key influence factor. Besides, firm size, growth and asset liquidity were also the influence factors. The size of the firm and growth had positive correlation with asset-liability ratio. Asset liquidity and profitability had negative correlation with asset-liability ratio.

\section{References}

[1] Collins, J.M. and Sekely, W.S. ((1972)) The Relationship of Headquarters Country and Industry Classification to Financial Structure. Financial Management, 12, 45-51.

[2] Schwartz, E. and Aronson, J.R. (1967) Some Surrogate Evidence in Support of the Concept of Optimal Financial Structure. Journal of Finance, 22, 10-18.

[3] Salehi, M. and Manesh, N.B. (2012) A Study of the Roles of Firm and Country on Specific Determinates in Capital Structure: Iranian Evidence. International Management Review, 8, 51-62.

[4] Harris, M. and Raviv, A. (1991) The Theory of Capital Structure. Journal of Finance, 46, 297-355. http://dx.doi.org/10.1111/j.1540-6261.1991.tb03753.x

[5] Mallikarjunappa, T. and Goveas, C. (2007) Factors Determining the Capital Structure of Pharmaceutical Companies in India. ICFAI Journal of Applied Finance, 13, 56-72.

[6] Baltaci, N. and Ayaydin, H. (2014) Firm, Country and Macroeconomic Determinants of Capital Structure: Evidence from Turkish Banking Sector. EMAJ: Emerging Markets Journal, 3, 47-58.

[7] Chang, C., Chen, X. and Liao, G. (2014) What Are the Reliably Important Determinants of Capital Structure in China? Pacific-Basin Finance Journal, 30, 87-113. http://dx.doi.org/10.1016/j.pacfin.2014.06.001

[8] Dong, Y., Liu, Z., Shen, Z., et al. (2014) Political Patronage and Capital Structure in China. Emerging Markets Finance \& Trade, 50, 102-125. http://dx.doi.org/10.2753/REE1540-496X500307

[9] Seelanatha, S.L. (2010) Determinants of Capital Structure: Further Evidence from China. Economics, Management \& Financial Markets, 5, 106-126.

[10] Warner, J.B. (1977) Bankruptcy Costs: Some Evidence. Journal of Finance, 32, 337-347. http://dx.doi.org/10.1111/j.1540-6261.1977.tb03274.x

[11] DeAngelo, H. and Masulis, R.W. (1980) Optimal Capital Structure under Corporate and Personal Taxation. Journal of Financial Economics, 8, 3-29. http://dx.doi.org/10.1016/0304-405X(80)90019-7

[12] Prowse, S.D. (1990) Institutional Investment Patterns and Corporate Financial Behavior in the United States and Japan. Journal of Financial Economics, 27, 43-66. http://dx.doi.org/10.1016/0304-405X(90)90020-Z 